\title{
Nowe ujęcia i koncepcje badawcze w studiach nad współczesnym miastem
}

Współczesne miasto znajduje się w stanie ciągłych zmian, co nie tylko stwarza trudności w identyfikacji jego oblicza, lecz także utrudnia studia nad tym zjawiskiem. Podobnie jak industrializacja wycisnęła swoje piętno na obliczu miasta XIX i początków XX w., tak okres postindustrialny spowodował zasadnicze zmiany miasta przełomu wieków XX i XXI. Organizacja i funkcjonowanie miasta postindustrialnego różni się znacznie od struktury miasta przemysłowego, wyrażonej w prostych, koncentrycznych i sektorowych modelach szkoły chicagowskiej lub miasta połowy XX w., z jego dominującą centralną dzielnicą biznesowa, inner city „niebieskich kołnierzyków" i rozprzestrzeniającymi się peryferiami zamieszkanymi przez klasę średnią. Współczesne duże miasto przedstawia luźno zorganizowany układ, cechujący się zanikiem tradycyjnego centrum i żywiołowym rozwojem coraz to nowych peryferyjnych przestrzeni rezydencjalnych. Wśród znaczących cech miasta postindustrialnego należy wymienić rozwój suburbiów, a także - a może przede wszystkim - transformację inner city. Obszary śródmiejskie, po kilku dekadach spadku zaludnienia, przeżywają obecnie ponowny rozwój, m.in. dzięki procesom gentryfikacji.

Jest rzeczą oczywista, że nowa forma i odmienne funkcjonowanie miasta wymuszały wypracowanie innych, różnych od tradycyjnych, ujęć i koncepcji badawczych. Cel opracowania stanowi przedstawienie tych rozwiązań, które wydają się najciekawsze, budząc największe nadzieje i poszerzając perspektywy badawcze. Wiele z nich rozwinęło się pod wpływem współczesnych orientacji filozoficzno-metodologicznych, obecnych w naukach społecznych i humanistycznych.

\section{Postpozytywistyczne zmiany w studiach miejskich}

Ostatnie trzy dekady $\mathrm{XX}$ w. to okres zasadniczych przemian myślenia teoretyczno-metodologicznego $\mathrm{w}$ studiach miejskich, które są związane z upadkiem pozytywistycznego wzorca badawczego. Ogólnie biorąc, o radykalnych zmianach decydowały trzy wzajemnie się wspomagające czynniki: 
- potrzeba wypracowania nowych konceptualizacji i narzędzi analitycznych, użytecznych w badaniu fenomenu miasta postindustrialnego lub miasta ery ponowoczesnej i cywilizacji informacyjnej;

- krytyka i rewizja zastanej wiedzy rozwijana z punktu widzenia postpozytywistycznych orientacji filozoficzno-metodologicznych, obecnych we współczesnych naukach społecznych i humanistycznych;

- zmiany generacyjne w środowisku badawczym, które wzmocniły krytykę tradycyjnych ujęć i osiągnięć badawczych.

Siły te generowały zmiany zarówno w płaszczyźnie metodologicznej (dzięki przyswajaniu w warsztatach badawczych coraz to nowych, rywalizujących ze sobą założeń filozoficzno-metodologicznych), jak i w płaszczyźnie teoretycznej - poprzez budowę nowych koncepcji teoretycznych i modeli na "gruzach" tradycyjnych teorii.

Należy pamiętać, że współczesne miasto, skupiające jak w soczewce najważniejsze procesy i patologie świata ponowoczesnego, stało się przedmiotem intensywnych badań wielu dyscyplin naukowych, wśród których należy wymienić przede wszystkim ekonomię, socjologię, antropologię kulturowa, geografię, urbanistykę oraz nauki o kulturze. Każda z nich wnosiła swoisty punkt widzenia i tradycje badawcze, co niewątpliwie wpłynęło na bogactwo i zróżnicowanie ujęć teoretyczno-metodo64 logicznych w studiach miejskich. Ów zasób „dóbr" naukowych trudno poddaje się systematyzacji, tym bardziej, że - ze względu na tendencje integracyjne we współczesnej nauce - „korzenie” określonych koncepcji wydają się trudne do ustalenia.

Próbując dokonać pewnego uporządkowania tego zasobu, można w pewnym uproszczeniu wyróżnić cztery nurty, w ramach których wyrastały nowe ujęcia i koncepcje badawcze: ekonomiczny lub polityczno-ekonomiczny; społeczny; kulturalny i humanistyczny. Nie sposób w krótkim zarysie omówić szczegółowo wszystkie koncepcje oraz ujęcia. W zawartym tu przeglądzie zaprezentowano te najbardziej emblematyczne dla współczesnych studiów miejskich.

\section{Nurt ekonomiczny i polityczno-ekonomiczny w badaniach współczesnego miasta}

Przedstawiciele tego nurtu rozpatrują miasto jako znamienny element kapitalistycznego sposobu produkcji i konsumpcji, koncentrując się na problematyce władzy, zarządzania miastem, zagadnieniach polityki miejskiej i sprawiedliwości społecznej. Ujęcia te, nazywane niekiedy nową socjologią miasta (por. Majer 2010), wywodzą się z marksistowskiej ekonomii politycznej oraz teorii krytycznej szkoły frankfurckiej. Ich celem jest 
nie tylko samo opisanie i wyjaśnienie rzeczywistości miejskiej, lecz także - poprzez negatywną ocenę status quo - wskazanie pewnych ograniczeń tradycyjnych teorii i koncepcji w badaniach miejskich. Procesy miejskie, takie jak restrukturyzacja przestrzeni, funkcjonowanie i rozwój miasta, rozpatrywane są w szerszej perspektywie zmian politycznych i społecznych.

Do czołowych przedstawicieli tego nurtu należą: David Harvey (por. 1973, 1982, 1996, 2001, 2003) i Manuel Castells (por. 1982, 1983, 1998). Ich prace wytyczyły nowy kierunek w studiach miejskich. Badacze ci, w przeciwieństwie do szkoły chicagowskiej, nie koncentrują się na „naturalnych" (ekologicznych) procesach rozwoju miast, lecz na systemach władzy społecznej i ekonomicznej, które znajdują swe odzwierciedlenie w przestrzeni miasta i jego funkcjonowaniu. Punktem wyjścia są dla nich nowe konceptualizacje miasta. Nowy okres w swych studiach - następujący po fazie pozytywistycznej - nazywa Harvey materializmem historyczno-geograficznym, stwierdzając, że stanowi on połączenie geograficznej wiedzy i wrażliwości z potencjałem ogólnych teorii społecznych ujętych w tradycji materializmu historycznego.

David Harvey przedstawia miasto jako centrum zainteresowania kapitału oraz główne miejsce walki klasowej. Jego zdaniem, przestrzeń miejska kształtuje się pod wpływem akumulacji kapitału i konfliktów klasowych. Głośne stały się jego analizy związków między neoliberalną transformacją kapitalizmu a przekształceniami współczesnej przestrzeni miejskiej. Jak stwierdza Harvey, przestrzeń miejska ulega ciągłej restrukturyzacji. O jej przebiegu decydują różne czynniki, takie jak decyzje lokalizacyjne wielkich przedsiębiorstw, stopień kontroli państwa nad gospodarką gruntami i produkcją przemysłową oraz interesy prywatnych inwestorów w zakresie obrotu nieruchomościami.

Manuel Castells traktuje miasto nie tylko jako wyodrębniony obszar (przestrzeń miejską), lecz także jako nierozłączną część procesów konsumpcji zbiorowej, będącej integralnym elementem kapitalizmu. Ujęcie Castellsa było podstawą studiów ewolucji miasta ery informacyjnej (tzw. miasta informacyjne). Analizując przestrzenne formy i procesy w społeczeństwie informacyjnym, wyróżnił dwa typy przestrzeni: przepływów i miejsc. Aby zrozumieć funkcjonowanie współczesnych miast, należy zbadać procesy zagospodarowania i przekształcania ich przestrzeni. Struktura funkcjonalno-przestrzenna miasta odzwierciedla walki i konflikty między różnymi grupami społecznymi. Jej oblicze jest wynikiem działania mechanizmów rynkowych oraz decyzji władz państwowych i regionalnych. Castells podkreśla też znaczenie walki upośledzonych społecznie grup o poprawę warunków życia. Znajdują one swój wyraz w różnego rodzaju ruchach społecznych, które działają na rzecz poprawy 
środowiska mieszkalnego, walczą z degradacją środowiska, bronią terenów zielonych oraz protestują przeciwko inicjatywom psującym charakter określonych dzielnic.

Ryszard Domański (2000) przedstawił koncepcję badania miasta innowacyjnego opartą na dwóch podstawach teoretycznych: teorii rekombinacji czynników produkcji Schumpetera i modelu struktur dyssypatywnych Prigogine'a. Ujęcie to zwraca uwagę na rolę relacji nieliniowych, kreatywności i innowacyjności w procesie rozwoju współczesnego miasta.

Koncepcja reżimu miejskiego, która pojawiła się w połowie lat 80 . XX w., oferuje szerokie możliwości analizy polityki miejskiej (por. Sagan 2000). Podejmując zagadnienia kontroli i władzy, pozwala wyjaśnić różnorodność odmiennych ścieżek rozwoju miast, dzięki odwołaniu się do lokalnych warunków i aktorów sceny miejskiej. Koncepcja ta, według niektórych (por. Elkin 1987; Stone 1989), stanowi teoretyczny schemat służący interpretacji związków przyczynowych w polityce miejskiej. Według M. S. Szczepańskiego i S. Nurka (1997), godzi podejścia zaliczane w socjologii miasta do nurtów szkoły humanistycznej i kulturalistycznej z ujęciami szkół makrostrukturalnych. W centrum uwagi znajdują się problemy kooperacji i koordynacji w działaniach różnych podmiotów na scenie miejskiej.

Zróżnicowany rozwój miast na przełomie XX i XXI w. prowadził 66 do powstania nowych narzędzi opisu i wyjaśniania tego zjawiska. Wśród różnych ujęć warto wymienić koncepcje miast globalnych (por. Sassen 1991) oraz miast postsocjalistycznych (por. Liszewski 2001).

\section{Ujęcie społeczne}

Nurt społeczny koncentruje się na ujęciach specyfiki struktur i procesów społecznych we współczesnym mieście, które cechują rosnące zróżnicowania i wykluczenia społeczne oraz zjawiska patologiczne. Warto wymienić kilka koncepcji, które można do tego nurtu zaklasyfikować.

Koncepcja miasta dualnego opisuje kierunek zmian struktury społecznej w dużych miastach (Lisowski 2000). Akcentuje kształtujący się nowy podział społeczności miejskiej, odmienny od zróżnicowań występujących w mieście połowy XX w. i stanowiący narzędzie opisu tej nowej, "docelowej" formy miasta. Warto podkreślić, że prostota schematów dualnych ma swoje walory analityczne $\mathrm{w}$ badaniach struktury wewnętrznej miasta, która ulega obecnie żywiołowej fragmentacji na "centrum" i margines. Opisując konsekwencje tego podziału, używa się często w badaniach koncepcji „wykluczenia społecznego”, które zwraca uwagę na czynniki powodujące, że jednostki i grupy społeczne tracą szansę wydobycia się $\mathrm{z}$ biedy i marginesu społecznego. 
Koncepcja gentryfikacji stała się podstawą opisu mechanizmu zmian we współczesnym mieście. Studia tego procesu przyczyniły się do zakwestionowania wielu uznanych i tradycyjnych teorii rozwoju i struktury miasta, m.in. ekologicznych modeli użytkowania ziemi w mieście, rozwiniętych w ramach szkoły chicagowskiej (por. Grzeszczak 2010). Studia te mają także swój wymiar metodologiczny, ponieważ stały się dogodnym „pojazdem”, którym do badań miejskich „wjechały” nowe orientacje metodologiczne i ujęcia badawcze, poczynając od strukturalistycznego ujęcia N. Smitha (1970), poprzez ujęcia liberalne D. Leya (1983), aż do ujęć postmodernistycznych S. Zukin (1987), feministycznych M. Gilbert (1997) i humanistycznych R. Webbera (2007). Badania nad gentryfikacją przyczyniły się do budowy nowej wiedzy o mieście postindustrialnym, podlegającym procesom zasadniczej restrukturyzacji, dając opis zmieniających się relacji między jego centrum a peryferiami, tendencji urbanizacyjnych oraz roli czynników ekonomicznych, społecznych i kulturowych.

Odmienne ujęcie wnosi koncepcja miasta jako areny procesów społecznych (por. Lisowski 1998) oraz „widowni”, w której toczy się życie codzienne mieszkańców. Teoretyczne inspiracje tej koncepcji odnoszą się do trzech nurtów socjologii XX w.: fenomenologii społecznej, etnometodologii i teorii dramaturgicznej. Dostarczają one aparatu pojęciowego do analizy zdarzeń społecznych, stanowiąc inspirujące ramy do badania życia codziennego miasta. Jedno z ujęć oparte jest na socjologii życia codziennego, która bada codzienne zdarzenia i praktyki uwikłane w społeczne konteksty (por. Sztompka 2008).

Kolejnym ujęciem jest koncepcja dramaturgiczna E. Goffmana (1959), która zakłada, że obecność innych ludzi przekształca nieuchronnie zachowania ludzkie w występ. Działania ludzi w życiu społecznym miasta przypominają akcję sceniczna, odbywającą się w pewnej przestrzeni, w której każda jednostka zajmuje określone miejsce, roszcząc sobie do niego pewne prawo i ograniczając dostęp innym. Przedmiotem analizy są tutaj zdarzenia powtarzalne, niekiedy wręcz cykliczne, rytmiczne i rutynowe, zlokalizowane $\mathrm{w}$ określonych miejscach, mające pewne ramy czasowe.

\section{Ujęcia kulturowe}

Nurt ten wyrasta z badań nad kultura, czerpiąc swe źródła z filozoficznego lub socjologicznego jej pojmowania. Wiele z tych analiz opiera się na tzw. filozofii miejskości (por. Paetzold 1996, 2000), która zawiera krytykę miasta i jego kultury.

Jednym $\mathrm{z}$ inspirujących ujęć $\mathrm{w}$ tym nurcie jest koncepcja opisująca miasto jako zdarzenie, a jego historię jako „tkankę” zdarzeń. Według 
E. Rewers (2005) jest to przejście od statycznej konceptualizacji miasta do wizji miasta "kinetycznego" jako pewnego rodzaju układu zdarzeniowego. Ujęcie to otwiera nowe perspektywy badań nad miastem, które obejmują problematykę nowości w mieście, znaczenie zmian w jego przestrzeni kulturowej oraz funkcjonowanie miasta w "ruchu”, przestrzeni i czasie. Centralną kategorią pojęciową w tym ujęciu jest zdarzenie, które może być pojmowane $\mathrm{w}$ dwojaki sposób:

- w szerszym sensie - jako stwarzanie nowych możliwości „stawania się" miasta i doświadczania przestrzeni miejskich;

- w węższym znaczeniu - jako efekt działania podjętego w ramach istniejących struktur miejskich.

Znaczenia te wytyczają dwa odmienne kierunki badań. Jeden, oparty na szerszym pojęciu zdarzenia, o charakterze poststrukturalistyczno-hermeneutycznym, kładzie nacisk na problem doświadczania przestrzeni kulturowej miasta jako pewnego rodzaju poznania filozoficznego. Pojęcie zdarzenia rozpatruje się tutaj $\mathrm{w}$ aspekcie powiązania i nawarstwiania wiązki zdarzeń konstytuujących życie w mieście (Rewers 2005). Stwarza to możliwość badania miasta jako palimpsestu, w którym tropi się ślady i pustki w przestrzeni kulturowej miasta. Pojęcie palimpsestu stało się podstawą analizy zmian krajobrazu kulturowego miast postsocjalistycznych w wyniku swoistych "czystek krajobrazowych" (usuwanie ikon socjalizmu), zmiany znaczenia zawartego w obiektach minionej epoki, nadawania nowych znaczeń (por. Czepczyński 2007). Drugi nurt, oparty na węższym znaczeniu zdarzenia, o charakterze geograficzno-urbanistycznym, akcentuje zmienność elementów i struktur miejskich. W tym ujęciu zdarzeniem jest postawienie lub wyburzenie budynku, zmiana jego fasady, wytyczenie nowej strefy komunikacyjnej, dojazd do pracy, zgromadzenie publiczne itp. (Maik 1993). Zdarzenia i ich rytmy czasowo-przestrzenne składają się na życie codzienne miasta, układają się w kompleksy o różnym stopniu złożoności (np. kompleks przemieszczania mieszkańców, zmian infrastrukturalnych lub funkcjonalnych).

Kolejne ujęcie oparte jest na pojęciu kultury wizualnej, które ujmuje wszystkie przyjęte $\mathrm{w}$ procesie socjalizacji sposoby myślenia, działania i odczuwania w kontekście wizualnego wymiaru rzeczywistości. Nurt ten ma swoją genezę w pracach dwóch teoretyków niemieckich, Georga Simmela i Waltera Benjamina, które stworzyły podstawy późniejszej analizy kultury wizualnej nowoczesnych miast. Wiele tych zagadnień zbiega się w metaforze flaneura, osoby, która spaceruje po mieście „leniwie”, obserwując widowisko miejskie.

Przedmiotem badań w tym nurcie jest „odczytywanie" miast jako tekstów, tzw. „czytanie” ich jako sensownych znaków, które są dostępne wizualnie mieszkańcom miast. Przykładem tego rodzaju rozważań są prace 
K. Lyncha (1960), Ch. Janksa (1989), K. M. McDonalda (1989) i F. Jamesona (1991). W swej słynnej analizie hotelu Bonaventura w Los Angeles, F. Jameson stwierdził, że budynek ten skupia w sobie zasadnicze aspekty ponowoczesnej kultury i życia, symbolizuje ogólne zagubienie i niezdolność umiejscowienia się człowieka w złożonym świecie ponowoczesnym. Należy podkreślić, że rozważania te, wychodząc $z$ analizy wizualnej miasta i jego budynków, mają wymiar szerszy, odnosząc się do charakteru współczesnej kultury i kondycji człowieka w tym świecie.

\section{Ujęcie humanistyczne}

Nurt humanistyczny wnosi do studiów miejskich nową problematykę badawczą i odmienne ujęcia, które koncentrują się na "niematerialnych" aspektach zjawisk miejskich. W centrum uwagi znajduje się człowiek, jego doświadczenia, percepcja, wartości. Ujęcia te nawiązują do tez obecnych w dziełach Platona, Rousseau, Thoreau, głoszących, że miasto powstaje w obronie przed bezradnością człowieka, tworząc w swej głębokiej istocie pewien rodzaj szczególnej i fundamentalnej więzi, która ukierunkowana jest na wzajemną pomoc (por. Sławek 2010). Wiele z ujęć humanistycznych opiera się na fenomenologii w wersji Husserla i Heideggera, które są w swej istocie próbami zrozumienia bytu i bycia człowieka.

W ujęciu K. Giedroycia (2003) i T. Sławka (2010) miasto rozpina się między miastem "dolnym”, stanowiącym siedlisko ludzkich spraw i złożony układ architektoniczno-urbanistyczny a miastem "górnym”, które rysuje się nam wtedy, gdy wydobywamy "głos" ludzkich dziejów i zamierzeń. $W$ tym drugim ujęciu, miasto jest zamiarem, utworzonym w celu odzyskiwania poczucia „my”. Miasto i jednostki ludzkie jawią się w tych rozważaniach jako dwa współdziałające i również nieukończone projekty, w których zasadniczą rolą odgrywa dystans między zamiarem a spełnieniem. W szerokim ujęciu miasto jest również palimpsestem nakładanych na siebie elementów, które mogą być odczytane dwojako: estetycznie - jako dominujące doświadczenie „potęgi” miasta i jego niekończących się możliwości ekspansji i filozoficznie - jako wezwanie do koniecznej redukcji w celu usunięcia warstw po to, aby zobaczyć to, co istotne i źródłowe. Ujęcie to „uruchamia” filozoficzny namysł nad miastem jako pewną ideą egzystencjalną. Warto dodać, że w geografii takie rozważania o miejskiej tożsamości przedstawił M. Madurowicz (2011) w szkicu na temat sporu $\mathrm{o}$ istnienie miasta.

Rodowód geograficzny ma koncepcja geografii humanistycznej miasta D. Jędrzejczyka (2004). Jej celem jest rozpatrywanie rzeczywistości miejskiej z punktu widzenia człowieka traktowanego jako podmiot, a nie 
przedmiot, jako Pascalowska „trzcina myśląca” czy też Heideggerowskie Sein und Zeit (por. Jędrzejczyk 2004: 15). Ujęcie to dąży do zrozumienia rzeczywistości miejskiej jako czegoś wyjątkowego. Realizacja tego celu wymaga zastosowania wielu metod współczesnej humanistyki, takich jak semiologia, hermeneutyka, lingwistyka i analiza poststrukturalistyczna. Ich pojęcia i koncepcje pozwalają zrozumieć samą istotę przestrzeni miejskiej, która jest projekcją różnych wartości kreowanych przez zróżnicowane kultury ludzkie. Geografia humanistyczna stawia w centrum uwagi człowieka jako kreatora świata wartości, rozpatrując miasto nie tylko w aspekcie struktur materialnych, lecz także „kodów” pozwalających odczytać i znaleźć sens ludzkiego życia, zarówno w wymiarze biologicznym, jak i metafizycznym.

\section{Szkoła kalifornijska jako opozycja wobec szkoły chicagowskiej}

Szkoła kalifornijska, zwana także szkołą Los Angeles, jest powszechnie traktowana jako przejście od modernistycznego spojrzenia na miasto, charakterystycznego dla szkoły chicagowskiej, do postmodernistycznego myślenia o rzeczywistości miejskiej. Ze względu na swą interdyscyplinarność nie mieści się w proponowanej wyżej klasyfikacji, obejmując programowo rozmaite aspekty rzeczywistości miejskiej - ekonomiczne, społeczne, kulturowe i humanistyczne.

Zasadniczym celem badaczy, utożsamiających się z tą szkoła, jest opis oraz interpretacja procesu tworzenia się miasta postmodernistycznego. Za idealne laboratorium służące analizie tego zjawiska uznano Los Angeles, nazywane niekiedy stolicą XX w.

Pod koniec XX w. ukazało się kilka prac próbujących opisać fenomen miasta postindustrialnego (postmodernistycznego). Jedną z nich jest zbiór opracowań pod redakcją A. J. Scotta i E. W. Soji (1996) pt. The city: Los Angeles and urban theory at the end of the twentieth century, ktory zawiera teksty głównych członków szkoły - poza redaktorami publikują tutaj M. Duneier, M. Dear, Ch. Jenk i J. Wolch. Opis przekształceń tego miasta został osadzony w szerszym kontekście uwarunkowań ponowoczesności i współczesnego, globalnego kapitalizmu (tzw. turbokapitalizmu) oraz nowych form urbanizacji (exopolis, cosmopolis, dual city, hybryd city, edge city). Z kolei praca M. Sorkina (1992), opisuje koniec tradycyjnego miasta modernistycznego, zbudowanego na szachownicy układów ulic i powstanie miasta postmodernistycznego, złożonego z kilku (kilkunastu) samodzielnych jednostek.

M. Cenzati (1993) nazwał szkołę kalifornijską projektem badań współczesnego urbanizmu, który łączy założenia szkoły frankfurckiej, wyrażo- 
ne w krytycznej teorii społecznej oraz postulaty szkoły chicagowskiej. Zdaniem przedstawicieli tej szkoły, połączenie tych ujęć tworzy podstawy nowego sposobu analizy współczesnego miasta przełomu XX i XXI w.

Szkoła kalifornijska nie jest zwartym stanowiskiem, lecz raczej zbiorem rozmaitych podejść. Jej znamienną cechą jest jej heterogeniczność, kształtowana $\mathrm{w}$ wyniku udziału przedstawicieli kilku dziedzin badawczych - geografów, planistów, urbanistów, socjologów i ekonomistów.

A. Majer (2010) wyróżnił kilka nurtów odmiennych stanowisk w ramach tej szkoły. Są to ujęcia:

- konfliktowe, które zakłada, że czynnikiem zmian w przestrzeni miejskiej jest narastanie konfliktów społecznych pojmowanych w świetle interesów klasowych;

- lokalizacyjne, reprezentowane w pracach geografów (Storper, Walker 1983);

- rynkowe, reprezentowane przez J. Logana i H. Molotcha (1987);

- zmian strukturalnych, obecne np. w pracach A. J. Scotta (2001);

- koncepcja „umiejscowienia” jako nowe pojęcie i narzędzie opisu, będące podstawą wyjaśniania w tzw. ekonomii politycznej miasta (por. Soja 2002);

- nowego regionalizmu, zawarte w pracach Soji $(2000,2008,2009)$.

Czynnikiem spajającym wysiłki badaczy szkoły kalifornijskiej są poszukiwania nowych sposobów analizy współczesnego miasta jako nowego, postfordowskiego i postmodernistycznego urbanizmu.

\section{Podsumowanie}

Powyższe rozważania upoważniają do sformułowania kilku wniosków.

Po pierwsze, wyzwolenie się badaczy miast z "okowów” koncepcji ekologii społecznej oraz wpływ rozmaitych postpozytywistycznych orientacji filozoficzno-metodologicznych otworzyły drogę do budowy nowych ujęć i koncepcji badawczych, odmiennych od metodologii szkoły chicagowskiej.

Po drugie, wielość proponowanych rozwiązań z trudem poddaje się systematyzacji, ponieważ wiele $\mathrm{z}$ nich ma charakter interdyscyplinarny i uwzględnia wielorakie aspekty rzeczywistości miejskiej. Jest zatem oczywiste, że proponowany podział ma charakter roboczy i dyskusyjny.

Po trzecie, niniejsze opracowanie przedstawia wybrane koncepcje i ujęcia badawcze, które autorowi wydają się istotne. Jest oczywiste, że wyczerpujący katalog rozwiązań w dziedzinie studiów miejskich przekracza ramy objętościowe tego opracowania. 


\section{Literatura}

Castells M. (1982), Kwestia miejska, PWN, Warszawa.

Castells M. (1983), The city and the grass roots. A cross-cultural theory of urban social movements, Edward Arnold, London.

Castells M. (1985), High technology, economic restructuring, and the urban-regional process in United States, [w:] M. Castells (ed.), High technology, space and society, Sage, Beverly Hills.

Castells M. (1998), End of Millenium, Blackwell, Oxford.

Cenzati M. (1993), Los Angeles and L.A. school: postmodernism and urban studies. Forum for Architecture and Urban Design, Los Angeles.

Czepczyński M. (2007), Podejścia badawcze w nowej geografii kultury, [w:] W. Maik, K. Rembowska, A. Suliborski (red.), Geografia a przemiany wspótczesnego świata, Wyd. Uczelniane Wyższej Szkoły Gospodarki, Bydgoszcz, s. 203-211.

Domański R. (2000), Miasto innowacyjne, „Studia KPZK PAN”, t. 59, Warszawa.

Elkin S. (1987), City and regime in the American Republic, University of Chicago Press, Chicago.

Giddens A. (2001), Sociology, Polity Press, London [wyd. pol. 2004, Socjologia, Wyd. Naukowe PWN, Warszawa].

Giedroyć K. (2009), Listy z dolnego miasta, Charaktery Sp. z o.o., Kielce.

Gilbert M. (1997), Feminism and differences in urban geography, "Urban Geography" 18, s. $166-179$.

Goffman E. (1959), The presentation of self in everyday life, Randon House, New York [wyd. pol. 2000, Człowiek w teatrze życia codziennego, Wydawnictwo KR, Warszawa].

Grzeszczak J. (2010), Gentryfikacja osadnictwa. Charakterystyka, rozwój koncepcji badawczej i przeglad wyjaśnień, Instytut Geografii i Przestrzennego Zagospodarowania PAN, Warszawa.

Harvey D. (1973), Social justice and the city, Edward Arnold, London.

Harvey D. (1982), The limits to capital, Blackwell, Oxford.

Harvey D. (1985), Consciousness and the urban experience. Studies in the history and theory of capitalist urbanization, Blackwell, Oxford.

Harvey D. (1996), Justice, nature and geography difference, Blackwell, New York.

Harvey D. (2001), Spaces of Capital, St. Martin Press, New York.

Harvey D. (2002), Paris, capital of modernity, Verso Books, New York.

Harvey D. (2003), Paris, capital of modernity, Verso Books, New York.

Harvey D. (2008), The right to the city, "New Left Review" 53, September/October, s. 23-40.

Harvey D. (2012), Rebel cities, Verso Books, New York [wyd. pol. 2012, Bunt miast, Fundacja Nowej Kultury Bęc Zmiana, Warszawa].

Jameson F. (1991), Postmodernizm or the cultural logic of late capitalism, Duke University Press, Durham [wyd. pol. 2011, Postmodernizm czyli logika kulturowa późnego kapitalizmu, Wyd. Uniwersytetu Jagiellońskiego, Kraków].

Janks C. (1989), What is postmodernizm, Academy, London.

Jędrzejczyk D. (2004), Geografia humanistyczna miasta, Dialog, Warszawa.

Ley D. (1983), A social geography of the city, Harper and Row, New York.

Lisowski A. (1998), Postmodernistyczna dekonstrukcja geografii miast, [w:] J. Kaczmarek (red.), Metodologia geografii osadnictwa na przełomie wieków, Katedra Geografii Miast i Turyzmu UŁ, Łódź, s. 31-39. 
Nowe ujęcia i koncepcje badawcze w studiach nad współczesnym miastem

Lisowski A. (2000), Dualne miasto - metafora z rzeczywistość, „Przegląd Geograficzny” t. 72, z. 3, s. 231-247.

Liszewski S. (2001), Model przemian przestrzeni miasta postsocjalistycznego, [w:] J. Jażdżewska (red.), Miasto postsocjalistyczne - organizacja przestrzeni miejskiej i jej przemiany, XIV Konserwatorium Wiedzy o Mieście, Łódź, s. 213-224.

Logan J. R., Molotch H. (1987), Urban fortunes. The political economy of place, University of California Press, Berkely.

Lynch K. (1960), The image of the city, Technology Press, Cambridge.

Maik W. (1993), Koncepcja lokalnych systemów osadniczych. Założenia i perspektywy badawcze, [w:] W. Maik (red.), Problematyka lokalnych systemów osadniczych, Wyd. Uniwersytetu Mikołaja Kopernika, Toruń, s. 19-28.

Maik W. (2011), Podstawy teoretyczno-metodologiczne studiów geograficzno-miejskich. Studium z metodologii geografii miast, Wyd. Uczelniane Wyższej Szkoły Gospodarki, Bydgoszcz.

Majer A. (2010), Socjologia i przestrzeń miejska, Wyd. Naukowe PWN, Warszawa.

McDonald K. M. (1989), Building respectability, “Sociology", Vol. 23, s. 55-80.

Paetzold H. (1996), The philosophical notion of the city, [w:] H. Paetzold (ed.), City life: essay on urban culture, Jan Van Eyck Academie, Maastricht.

Paetzold H. (2000), Symbol, culture, city, Jan Van Eyck Academie, Maastricht.

Rewers E. (2005), Post-polis. Wstęp do filozofii ponowoczesnego miasta, Universitas, Kraków.

Sagan J. (2000), Miasto. Scena konfliktów i wspótpracy, Wyd. Uniwersytetu Gdańskiego, Gdańsk.

Sassen S. (1991), The global city: New York, London, Tokyo, Princeton University Press, Princeton.

Scott A. J. (2001), Global city-regions, Oxford University Press, New York.

Scott A. J., Soja E. [eds.] (1996), The city: Los Angeles and urban theory at the end of the twentieth century, University of California Press, Berkeley.

Sławek T. (2010), Miasto. Próba zrozumienia, [w:] E. Rewers (red.), Miasto w sztuce - sztuka miasta, Universitas, Kraków, s. 17-69.

Smith N. (1970), Toward a theory of gentrification; a back to the city movement by capital not people, "Journal of American Planning Association", Vol. 45, s. 538-548.

Soja E. (2000), Postmetropolis: critical studies of cities and regions, Blackwell, Oxford.

Soja E. (2002), The new regionalism; a conversation with Edward Soja. Interview by R. Ehrenforst, "Critical Planning" 9, s. 5-12.

Soja E. (2008), Tacking space personally, [w:] B. Warf, S. Arias (eds.), The spatial form; interdisciplinary perspectives, Routledge, New York-London, s. 11-34.

Soja E. (2009), Regional Planning and development theories, [w:] N. Thrift, R. Kitchin (eds.), The International Encyklopedia of Human Geography, Eisevier, Amsterdam, s. 259-270.

Sorkin H. (1992), Variations on a theme park: the new American city and the end of public space, Noonday, New York.

Stone C. (1989), Regime politics: governing Atlanta, University Press of Kansas, Laurence.

Storper M., Walker R. A. (1983), The theory of labour and the theory of location, "International Journal of Urban and Regional Research", Vol. 7.

Suliborski A. (2001), Funkcja i struktura funkcjonowania miast. Studia empiryczno-teoretyczne, Wyd. Uniwersytetu Łódzkiego, Łódź.

Suliborski A. (2010), Funkcjonalizm w polskiej geografii miast. Studia nad geneza i pojęciem funkcji, Wyd. Uniwersytetu Łódzkiego, Łódź. 
Szczepański M. S., Nurek S. (1997), Miasto i świat społeczny jego mieszkańców w perspektywie socjologicznej (szkic do syntezy), [w:] J. Kaczmarek (red.), Współczesne przemiany struktur przestrzennych dużych miast, IX Konserwatorium Wiedzy o Mieście, ŁTN, Łódź.

Sztompka P. (2008), Życie codzienne - temat najnowszej socjologii, [w:] P. Sztompka, M. Bogunia-Borowska (red.), Socjologia codzienności, Znak, Kraków, s. 15-22.

Webber F. (2007), The metropolitan habitus: its manifestation, locations, and consumption profiles, "Environment and Planning A", Vol. 39, No. 1, s. 182-207.

Zukin S. (1987), Gentrification: culture and capital in the urban core, "Annual Review of Sociology", Vol. 13, s. 129-147.

Wiesław Maik, prof. dr hab., Katedra Gospodarki Turystycznej, Wyższa Szkoła Gospodarki w Bydgoszczy 